\title{
Comparison of experimental wound healing in quail using two types of commercial hemostatic dressings
}

\section{Comparação da cicatrização experimental de feridas em codornas usando dois tipos de curativos hemostáticos comerciais}

\author{
Tainá M. P. Chiquito ${ }^{\star *}\left(\mathbb{D}\right.$, Margarete K. Falbo ${ }^{1}$, Rafael V. Soares ${ }^{1} \mathbb{C}^{\circ}$, \\ Roberta A. Marcondes ${ }^{1}\left(\mathbb{D}\right.$, Jayme A. Peres ${ }^{1}\left(\mathbb{D}\right.$, Sharlenne L. S. Monteiro ${ }^{1}(\mathbb{D}$, \\ Katherinne M. Spercoski ${ }^{(0)}$, Giuliana G. Kasecker ${ }^{1}$ (1)
}

\begin{abstract}
The use of powdered hemostatic products and propolis-based preparations has become increasingly common to control bleeding and aid healing. This study evaluated two hemostatic dressings, one based on propolis $\left(\right.$ Alveolex $\left.{ }^{\circledR}\right)$ and the other on ferric subsulfate powder (Quick Blood Stopper ${ }^{\circledR}$ ), on experimental wound in quails. The experiment was conducted with 36 quails assigned to three groups: control, propolis-based hemostatic dressing and ferric subsulfatebased hemostatic dressing, on two types of wounds, superficial (skin and subcutaneous) and deep (skin, subcutaneous and muscle). Pre- (day-7) and post-procedure (days 2 and 10) examinations showed a tendency to reduce hematocrit values on day 2 and a tendency to increase fibrinogen levels and total leukocyte count on the same day. Visual assessment of wound healing indicated that birds using Quick Blood Stopper ${ }^{\circledR}$ showed signs of poor healing, while the group treated with Alveolex ${ }^{\circledR}$ had uncomplicated healing within the expected time. The groups treated with hemostatic based on ferric subsulfate showed a tendency to increase the values of fecal corticosterone metabolites on day 10, suggesting an increased level of stress in these animals. During the surgical procedure, both hemostatic products controlled bleeding, but Alveolex ${ }^{\circledR}$ was more efficient and easy to handle.
\end{abstract}

KEYWORDS: fecal corticosterone, ferric subsulfate, hemogram, lesion, própolis

RESUMO: A adoção de hemostáticos em pó e preparações à base de própolis tem se tornado cada vez mais comum para realizar o controle de sangramentos e auxiliar na cicatrizaçáo. Neste trabalho foram avaliados dois curativos hemostáticos, um à base de própolis $\left(\right.$ Alveolex $^{\circledR}$ ) e outro em pó à base de subsulfato férrico (Quick Blood Stopper ${ }^{\circledR}$ ), após lesão experimental em codornas. O experimento foi realizado com 36 codornas, separadas em três grupos: controle, hemostático à base de própolis e hemostático à base de subsulfato férrico, submetidos a dois tipos de feridas, superficiais (pele e subcutâneo) e profundas (pele, subcutâneo e musculatura). Os exames pré (dia -7) e pós procedimento (dias 2 e 10) demonstraram uma tendência à reduçáo dos valores de hematócrito no dia 2 e tendência ao aumento dos níveis de fibrinogênio e contagem de leucócitos totais neste mesmo dia. A avaliação visual da cicatrização da ferida demonstrou que as aves submetidas ao Quick Blood Stopper ${ }^{\circledast}$ exibiram sinais de dificuldade na cicatrização, enquanto o grupo tratado com Alveolex ${ }^{\circledR}$ apresentou cicatrização sem complicaçóes e dentro do tempo esperado. Os grupos tratados com hemostáticos baseados em subsulfato férrico mostraram uma tendência a aumentar os valores dos metabólitos de corticosterona fecal no $10^{\circ}$ dia, sugerindo um aumento do nível de estresse nestes animais. Durante o procedimento cirúrgico, ambos os produtos hemostáticos controlaram o sangramento, porém o Alveolex ${ }^{\circledR}$ foi mais eficiente e de fácil manipulação.

PALAVRAS-CHAVE: corticosterona fecal, subsulfato férrico, hemograma, lesão, própolis 


\section{INTRODUCTION}

In birds, wounds can be caused by animal bites, self-mutilation, neoplasms, injury during entrapment, among others, but the main cause remains the trauma (MICKELSON; MANS; COLOPY, 2016).

The process of wound healing in birds is similar to that observed in mammals, being a complex process composed of phases such as coagulation, inflammation, proliferation and remodeling. These are discrete phases that are interrelated and can overlap, but they occur spontaneously in response to an injury (PORTOU et al., 2015).

The use of a topical product that reduces wound healing time in poultry patients is invaluable as it would reduce immobilization time and reduce patient stress associated with bandage management (RITZMAN, 2004).

In this context, the present study aimed to evaluate two hemostatic dressings, a propolis-based product and a ferric subsulfate-based powder preparation on experimental wound in quails.

\section{MATERIAL AND METHODS}

The experiment was carried out with the approval from the Ethics Committee for the Use of Animals under protocol 011/2018 of Universidade Estadual do Centro-Oeste (CEDETEG/ UNICENTRO), with 36 quails (Coturnix coturnix japonica), using two types of hemostatic dressings, one based on propolis $\left(\right.$ Alveolex ${ }^{\circledR 1}$ ) and the other, a powder hemostatic dressing based on ferric subsulfate (Quick Blood Stopper ${ }^{2}$ ), to treat two types of wounds, superficial wound with acute lesion of skin and subcutaneous tissue in the femoral region of the right pelvic limb, approximately $2 \mathrm{~cm}$ in length or deep wound with the same length but progressing to the musculature.

Animals were assigned to three groups with 12 animals each: a control group (C), a group treated with Alveolex ${ }^{\circledR}(\mathrm{AL})$ and a group treated with hemostatic powder, Quick Blood Stopper $^{\circledast}(\mathrm{SF})$. Each group was subdivided into two, with six animals, to be subjected to the types of wounds. The groups were distributed as follows: 1) Superficial wound without dressing (CS); 2) Deep wound without dressing (CP); 3) Superficial wound using propolis-based dressing (ALS); 4) Deep wound using propolis-based dressing (ALP); 5) Superficial wound using ferric subsulfate-based dressing (SFS); and 6) Deep wound using ferric subsulfate-based dressing (SFP).

Three blood samples were taken from all birds during the experimental period. In the preoperative period, blood was drawn for blood count and fibrinogen determination seven days before the surgical procedure (day 7) and in the postoperative period, new samples were taken for the same tests, two days (day 2) and ten days (day 10) after the surgical procedure.
Venipuncture was performed in the jugular vein, preferably on the right side, and up to $0.7 \mathrm{~mL}$ of blood was collected in $1.5 \mathrm{~mL}$ microtubes containing 1.5 to $2 \mathrm{mg} / \mathrm{mL}$ EDTA (Ethylenediamine Tetraacetic Acid). All samples were processed on the same day of collection.

Blood count was performed manually, including hematocrit, red blood cell count, differential cell count and leukogram, as well as the measurement of fibrinogen by the heat separation method (LUMEIJ, 2008).

Hematocrit was determined using the microhematocrit method and red blood cell count using the Neubauer chamber after dilution in Natt and Herrick's solution, performing the quadrant count for large cells (CAMPBELL, 2010). The leukogram was performed using the estimation method, through observation of the blood smear under a 40x objective lens, considering ten fields, on average, using the correction factor of 1,500 (KENNETH; BIENZLE, 2010).

The surgical procedure was performed in a sterile environment, using aseptic techniques. The preparation of the patient consisted of removing the feathers in the region of the lesion, and antisepsis with topical povidone iodine. Lesions were made with a number 10 scalpel blade, followed by the placement of hemostatic dressing according to each subgroup evaluated, except for the control groups. After applying the dressings or just compressing the wound as performed in the control group, skin was sutured in animals with superficial wounds (synthetic non-absorbable thread, 4-0 caliber) and muscles and skin were sutured in animals with deep wounds (synthetic absorbable thread and synthetic non-absorbable thread, respectively, both 4-0 caliber). In animals treated with the powdered hemostatic dressing, the wound was washed with saline solution after hemostasis, and in animals treated with the propolis-based hemostatic dressing, this procedure was not necessary.

Postoperatively, healing time was evaluated with daily evaluation of the wound and description of clinical findings. Suture removal in all animals was possible on the tenth postoperative day. The findings observed and evaluated for intensity were tabulated according to the presence of: edema; bruise; and crust formation. Each parameter was graded as: 0 (absent), 1 (low intensity), 2 (moderate) and 3 (intense) and thus each bird received a healing assessment score at the end of the tenth day, according to the sum of the scores of the findings, with adaptation described by Singer et al. (2007) and Hollander et al. (1995).

In order to check the correlation between the different treatments and the stress response in the animals, fecal samples (corresponding to 24 hours of production) were collected seven days before the surgical procedure and ten days after.

\footnotetext{
${ }^{1}$ Alveolex: propolis-based alveolar dressing (10\%), iodoform (5\%), beeswax and thickener, produced by Biodinâmica química e farmacêutica LTDA, Brazil.

${ }^{2}$ Quick Blood Stopper: ferric subsulfate-based antiseptic powder, produced by Four Paws LTDA, USA.
} 
Fecal extraction and hormone quantification were performed in the Laboratory of Reproductive Physiology, Federal University of Paraná, Curitiba, state of Paraná. All reagents (except when specified) were purchased from Sigma-Aldrich (São Paulo, Brazil) and all solutions were prepared with Milli-Q water. Fecal extraction was performed according to the methods of Brown; Walker; Steinmain (2004), with slight modifications. Briefly, an aliquot of $0.5 \mathrm{~g}$ of the thawed, well mixed, wet fecal sample was placed in a glass tube containing $3 \mathrm{~mL} 99.3 \%$ methanol and $2 \mathrm{~mL}$ distilled water, and was vigorously shaken for $30 \mathrm{~min}$ using a Multi-Pulse vortexer (Glas-Col, Terre Haute, IN). Each sample was centrifuged $(1,000 \mathrm{~g}, 15 \mathrm{~min})$, the supernatant was recovered and stored at $-20^{\circ} \mathrm{C}$ until analysis. Fecal corticosterone metabolites were quantified by enzyme-immunoassay. Antibody for corticosterone (Polyclonal CJM006; 1:12,000 dilution) was obtained from the University of California, Davis, CA, USA. Polyclonal CJM006 cross-reacts with 100\% cortisol, $9.9 \%$ prednisolone, $6.3 \%$ prednisone, $5.0 \%$ cortisone, $0.7 \%$ corticosterone, $0.3 \%$ deoxycorticosterone and 0.5\% 21-deoxycortisone (BOTELHO et al. 2015). Assay sensitivity was $78 \mathrm{pg} / \mathrm{mL}$, cv inter-assay was $<15 \%$ and intra-assay was $<10 \%$. Results were calculated in ng/g urofecal material.

Data on hematocrit, fibrinogen dosage, total leukocytes, measurement of fecal corticosterone metabolites and wound scores were tested for normality and, with normal distribution, one-way analysis of variance was applied, followed by Tukey's post hoc test, using the GraphPad Prism 3.0 Software, considering $\mathrm{p}<0.05$.

\section{RESULTS AND DISCUSSION}
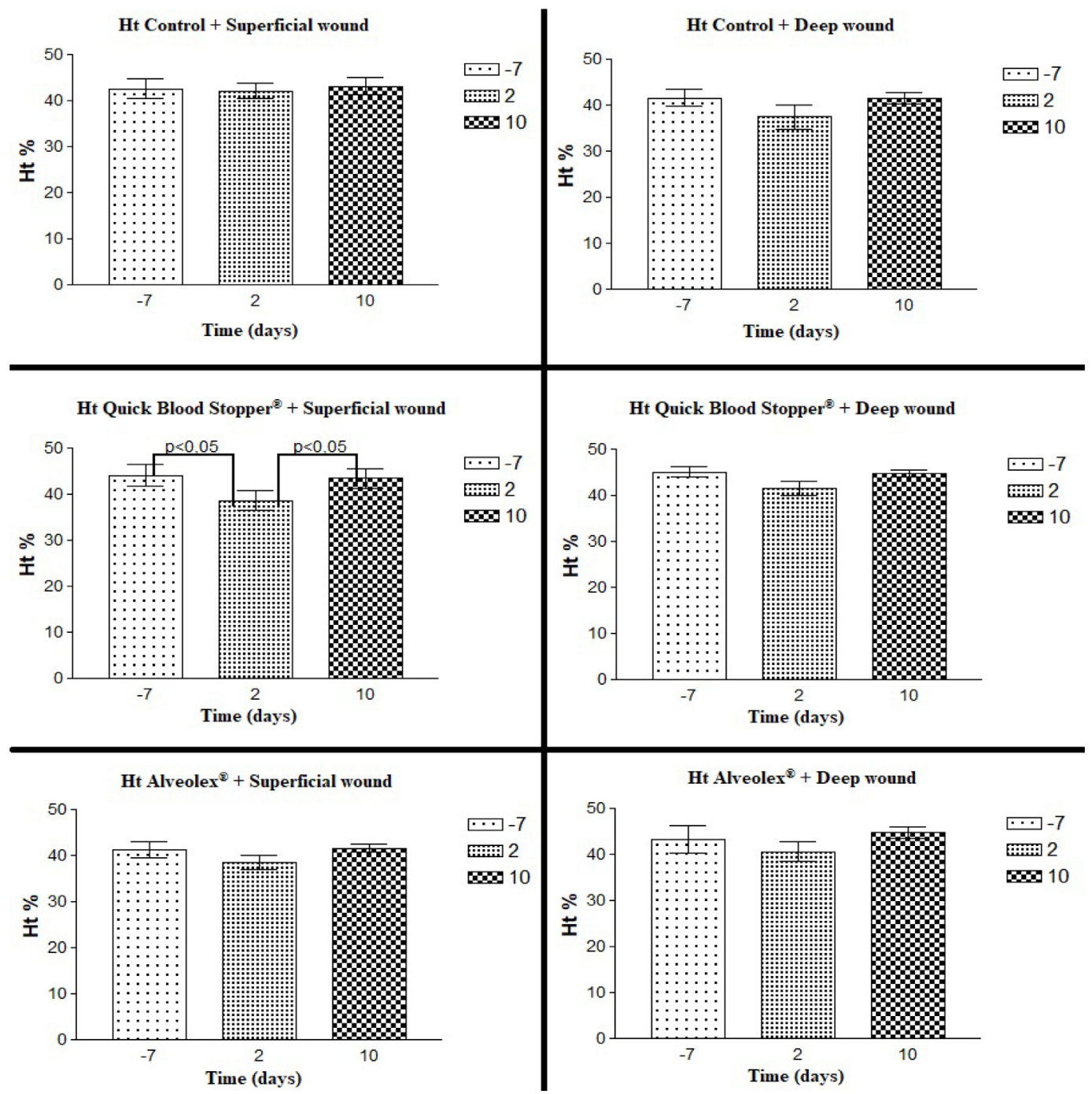

Graph generated after statistical analysis, by the program Prism 3.0, from the data obtained in this experiment.

Figure 1. Hematocrit values of quails subjected to experimental wounds and different hemostatic protocols. Data are represented as mean \pm standard error. P-values are expressed in the figures where significant differences were detected (Ht= hematocrit; Control=

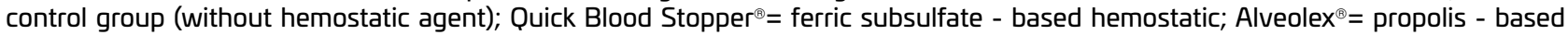
hemostatic dressing; Superficial wound= wound made on the skin and subcutaneous tissue; Deep wound = injury to skin, subcutaneous tissue and muscle; -7 = seven days before surgery; 2 = two days after surgery; 10 = ten days after surgery). 
Hematocrit values tended to decrease on day 2 in all groups, significantly in the group with superficial wound treated with Quick Blood Stopper ${ }^{\circledR}(p<0.05)$, which may in part be attributed to blood loss in the transoperative period (Figure 1).

In the study by Lichtenberger et al. (2009) regarding acute blood loss in ducks, red blood cell regeneration began to occur 24 hours after blood loss, with regenerative changes, such as the presence of polychromasia during the 48-hour period when the assessment was performed at the end of the study. There was a tendency to decrease hematocrit values of the birds two days after the surgical procedure, but there were no significant clinical changes in the birds and, 10 days after the procedure, the values returned to the initial ones.
According to Fair; Whitaker; Pearson (2007), hematocrit evaluation is not only based on red blood cell concentration, but also on the size of these cells, and cannot be used as the sole source of information. The hematocrit should be associated with other blood tests, such as hemoglobin concentration, white cells and plasma protein concentration, in addition to the clinical examination of the animal.

Regarding fibrinogen levels, there was a tendency to increase on day 2 in all groups, although in the group with superficial wound treated with Alveolex ${ }^{\oplus}$ this increase indicates an inflammatory response due to tissue damage, since fibrinogen in birds is an acute phase protein and an important
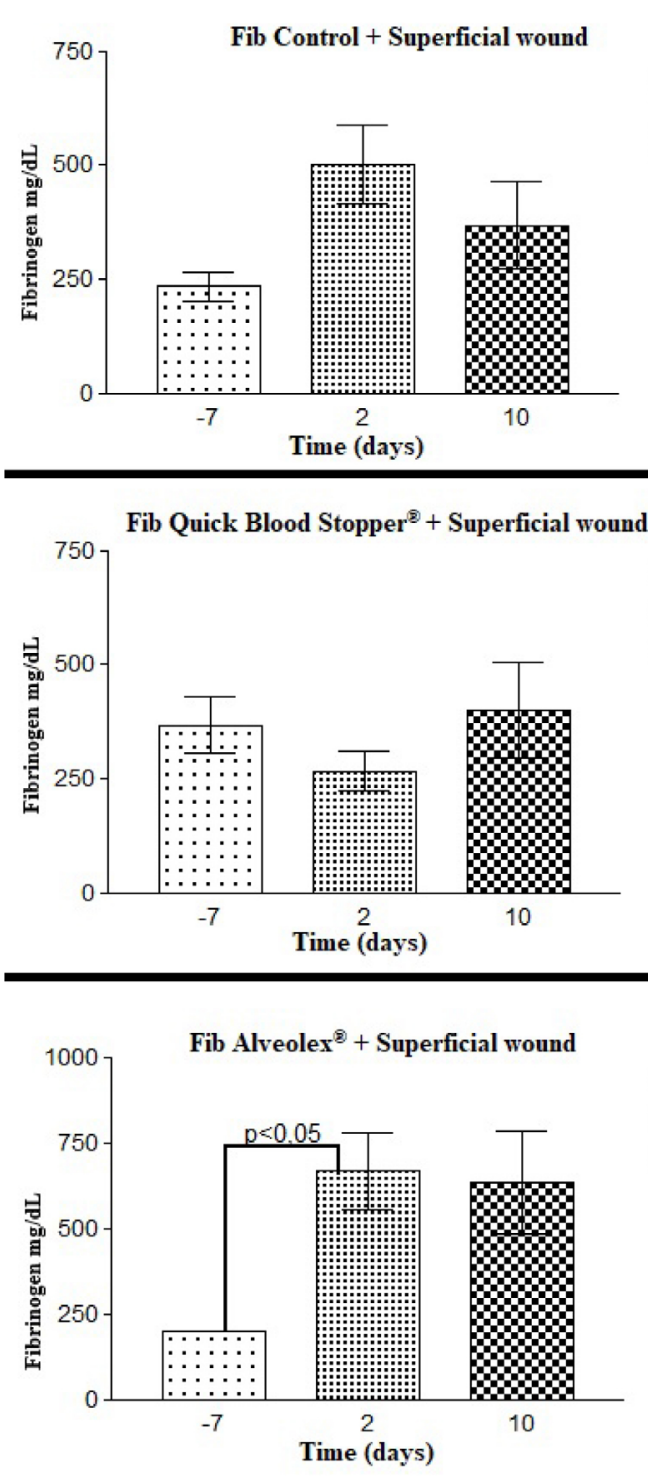

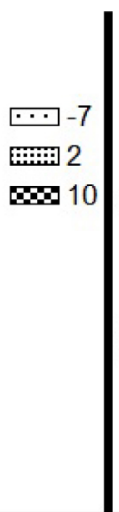

Fib Control + Deep wound

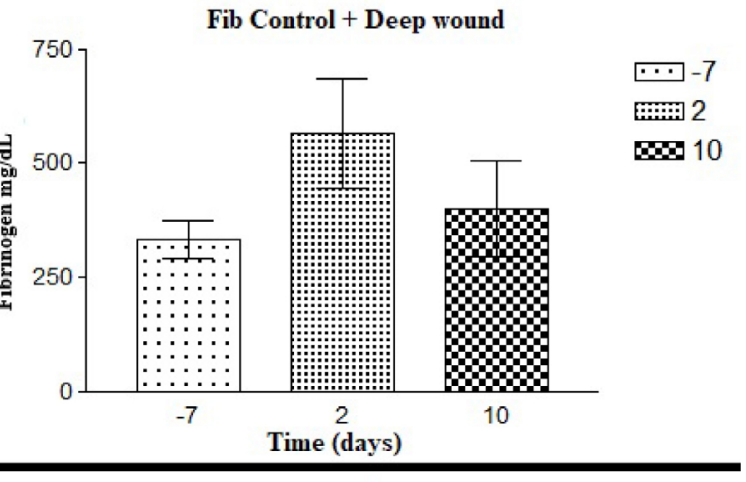

Fib Quick Blood Stopper ${ }^{2}+$ Deep wound
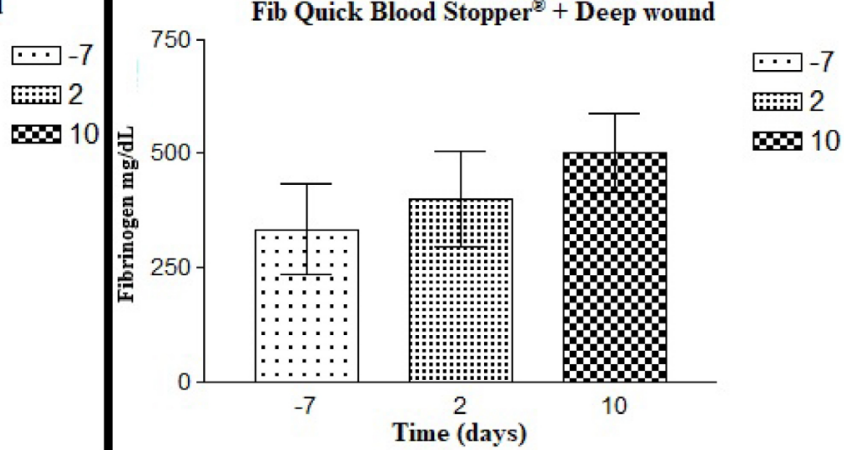

Q⿻日木 10

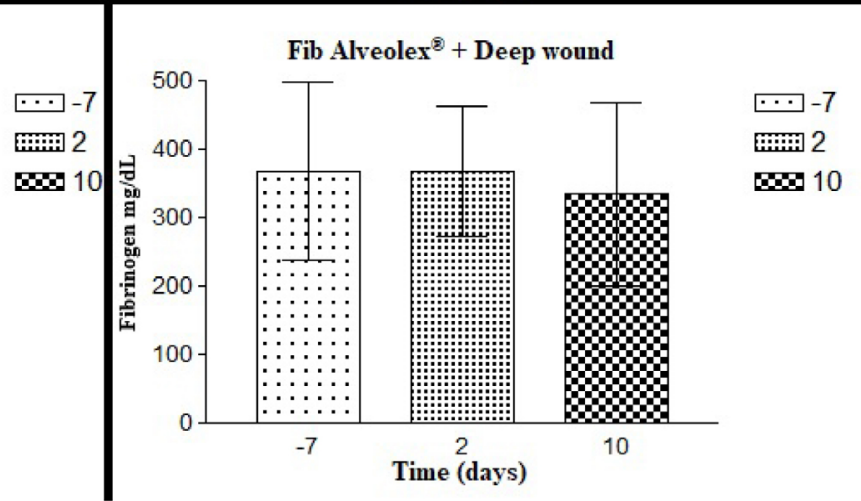

Graph generated after statistical analysis, by the program Prism 3.0, from the data obtained in this experiment.

Figure 2. Fibrinogen values of quails subjected to experimental wounds and different hemostatic protocols. Data are represented as mean \pm standard error. P-values are expressed in the figures where significant differences were detected. (Fib = fibrinogen; Control $=$ control group (without hemostatic agent); Quick Blood Stopper ${ }^{\oplus}=$ ferric subsulfate-based hemostatic; Alveolex ${ }^{\circledR}=$ propolis-based hemostatic dressing; Superficial wound = wound made on the skin and subcutaneous tissue; Deep wound = injury to skin, subcutaneous tissue and muscle; -7 = seven days before surgery; 2 = two days after surgery; 10 = ten days after surgery). 
marker of inflammation (DAVALOS; AKASSAGLOU, 2012; ARAÚJO et al., 2017) (Figure 2).

In chickens, Georgieva et al. (2010) reported that plasma fibrinogen concentration increased after infection of birds with $E$. coli and E. tenella, and suggested that fibrinogen is a reliable indicator of inflammation, infection and also when soft tissue damage occurs.

Leukocyte response tended to increase in all groups on day 2, with significance for the control and Alveolex ${ }^{\circledR}$ groups subjected to superficial wound (Figure 3).

The healing response in birds occurs by mobilizing, mainly, heterophiles and monocytes to the lesion site, being compatible with the observed events. The proliferation phase is characterized by the presence of white blood cells, mainly heterophiles and monocytes. Heterophiles are responsible for phagocytizing organisms and debris that contaminate the wound. Monocytes, which are transformed into macrophages in injured tissues, are essential for wound healing, as these cells synthesize and secrete growth factors, responsible for the tissue remodeling phase. Macrophages are also responsible for stimulating angiogenesis, recruiting mesenchymal cells and modulating the production of the collagen matrix in the wound (BALSA; CULP, 2015).

In the evaluation of the wound score, there was a statistical difference between the group with deep wound treated with Quick Blood Stopper ${ }^{\circledR}$ and the control group with deep
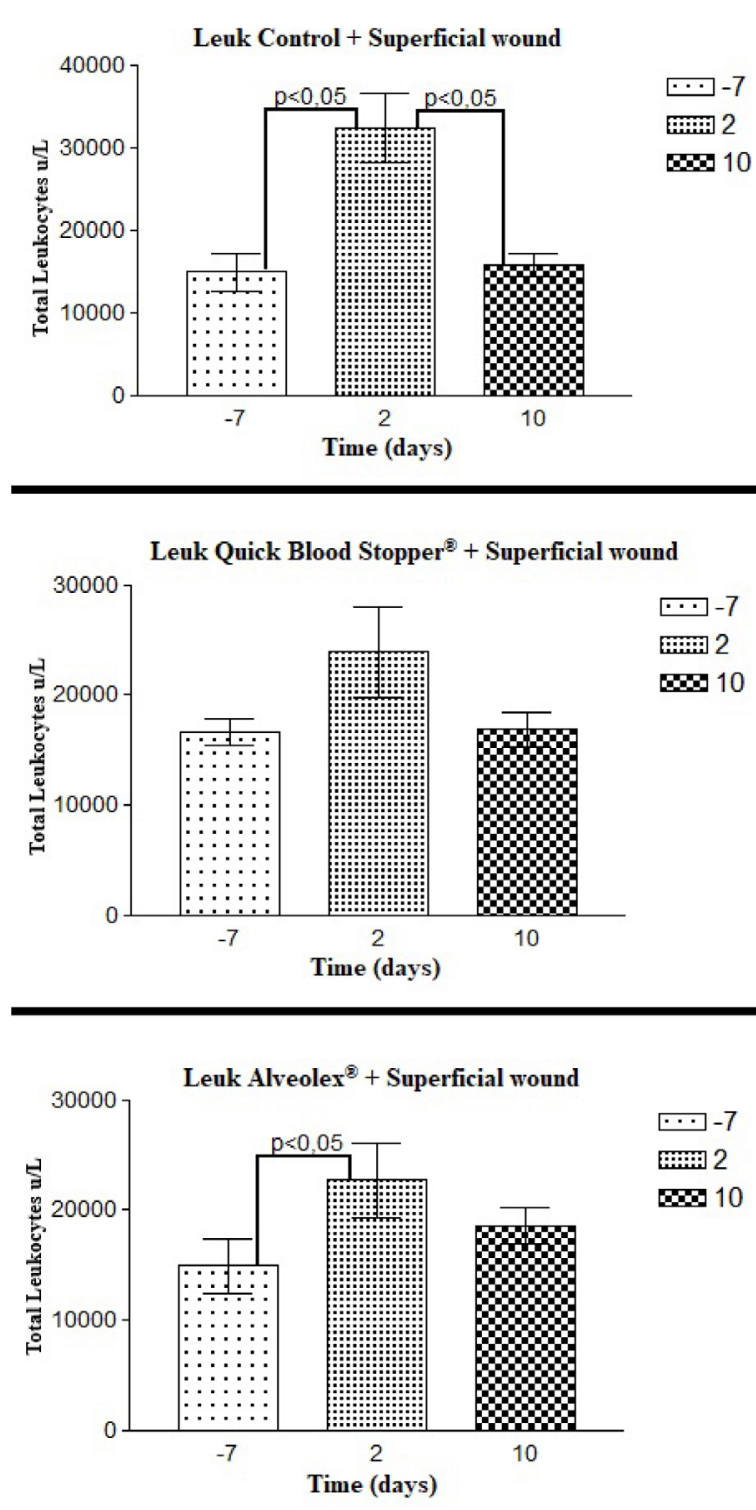
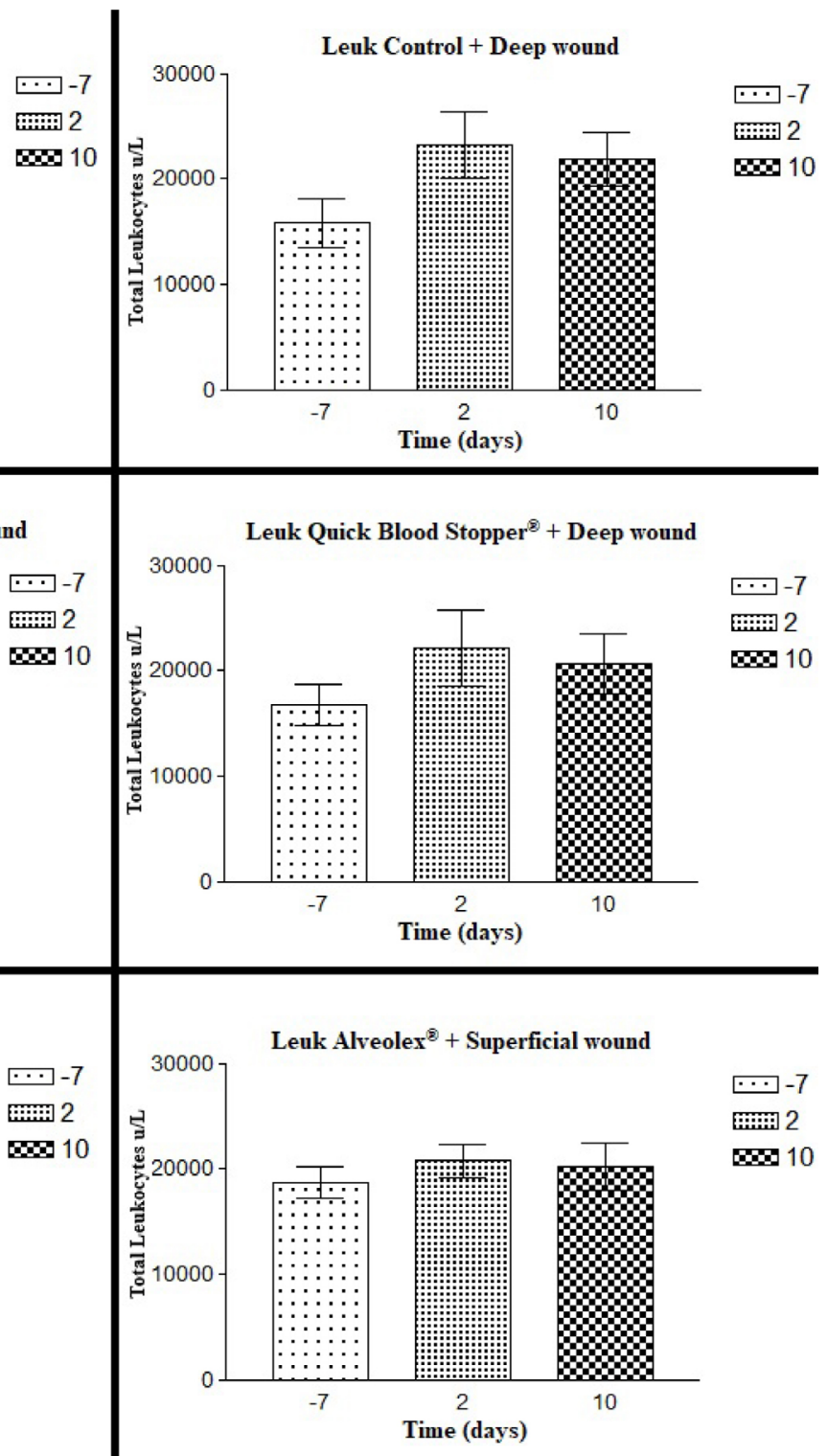

Graph generated after statistical analysis, by the program Prism 3.0, from the data obtained in this experiment.

Figure 3. Total leukocyte values in quails subjected to experimental wounds and different hemostatic protocols. Data are represented as mean \pm standard error. P-values are expressed in the figures where significant differences were detected. (Leuk = total leukocytes; Control = control group (without hemostatic agent); Quick Blood Stopper ${ }^{\oplus}=$ ferric subsulfate-based hemostatic; Alveolex ${ }^{\oplus}=$ propolisbased hemostatic dressing; Superficial wound = wound made on the skin and subcutaneous tissue; Deep wound = injury to skin, subcutaneous tissue and muscle; -7 = seven days before surgery; 2 = two days after surgery; 10 = ten days after surgery). 
wound, and the group with superficial wound treated with Alveolex ${ }^{\oplus}(p<0.05)$. The group treated with Quick Blood Stopper ${ }^{\circledR}$ showed higher values in the score, showing that healing was more affected, whereas groups treated with Alveolex ${ }^{\oplus}$ presented values close to the control groups, indicating that both groups did not present interferences harmful to healing (Figure 4).

Considering the hemostatic powder based on Quick Blood Stopper ${ }^{\oplus}$, there were difficulties in handling the product and applying it on the wound, requiring a considerably larger amount of product compared to Alveolex ${ }^{\oplus}$, making the bleeding period slightly longer.

In a study by Scarano et al. (2012), ferric subsulfate was used to control bleeding in human dentistry due to its hemostatic effect, as it has extremely low $\mathrm{pH}$ and causes rapid intravascular coagulation. However, in this study, there was no statistical difference when ferric subsulfate was used as a hemostatic substance in relation to the control and there was an efficient hemostasis in six cases out of ten that were used.

Byun et al. (2018) used ferric subsulfate in surgical lesions on the tail of rats, and reported that the substance was effective for hemostasis. However, it causes cytotoxicity to fibroblasts and its use should be considered in clinical form.

In birds using Alveolex ${ }^{\circledast}$, the response in wound healing was similar to that of the control group. During surgery, the propolis-based hemostatic agent was easy to handle and apply to the wound, stopping bleeding almost immediately, with minimal blood loss, speeding up the repair process.

Alveolex ${ }^{\oplus}$ is already used in human dentistry to prevent alveolitis and lessen pain after tooth extraction. This product stimulated bone tissue formation and prevented bone resorption in experimental wounds in rat parietal bone, showing antiinflammatory and antimicrobial activity (PEREIRA et al., 2012).

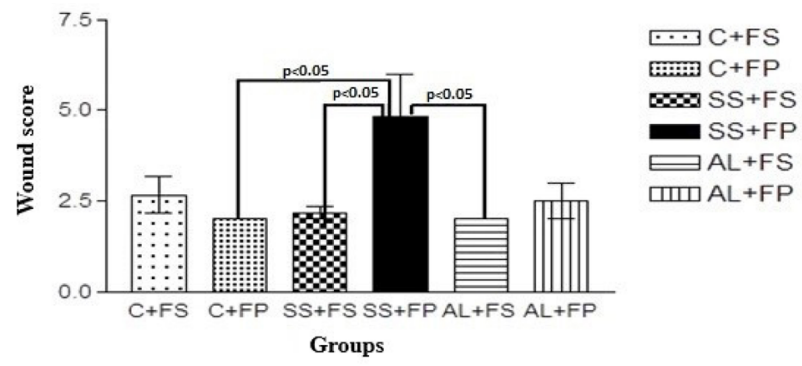

Graph generated after statistical analysis, by the program Prism 3.0, from the data obtained in this experiment.

Figure 4. Visual assessment of wounds, using an adapted score in quails subjected to experimental wounds and different hemostatic protocols. Data are represented as mean \pm standard error. P-values are expressed in the figures where significant differences were detected ( $\mathrm{C}+\mathrm{FS}=$ Control group with superficial wound; $\mathrm{C}+\mathrm{FP}=$ Control group with deep wound; SS+FS = Quick Blood Stopper ${ }^{\circledast}$ group with superficial wound; SS+FP = Quick Blood Stopper ${ }^{\circledast}$ group with deep wound; AL+FS = Alveolex ${ }^{\circledast}$ group with superficial wound; $A L+F P=$ Alveolex $^{\circledR}$ group with deep wound.
In another study by Sehn et al. (2009), experimental wounds were made in rats, with surgical procedure and anesthesia, using a postoperative propolis-based ointment, which influenced the skin healing process, stimulated keratinocyte proliferation and accelerated the healing process, findings compatible with what was observed in the present study with domestic quails.

Regarding the level of fecal corticosterone metabolites, data were presented as an increase or a decrease from day 0 of treatment (baseline), enabling the occurrence of negative values, when groups have displayed a reduction in fecal corticosterone metabolites during the experimental period. The groups treated with hemostatic based on ferric subsulfate showed a tendency to increase the values in relation to baseline $(p=0.054)$ on day 10 , suggesting a relationship between the other data that demonstrate impaired healing and increased levels of stress in these animals (Figure 5).

In a study conducted by Durant et al. (2016), superficial wounds were made on the left pelvic limb of the common starling (Sturnus vulgaris) and the healing time after chronic stress was assessed by measuring corticosterone. The average healing time was 11 days and the birds with the lowest corticosterone levels healed more quickly. In the present study, it was possible to observe similar results, since the birds in the group treated with ferric subsulfate had increased levels of fecal corticosterone metabolites on day 10 , in addition to demonstrating more healing disorders compared to the other groups.

The main benefit in measuring fecal corticosterone metabolites is the non-invasive collection of samples, using feces produced within a 24-hour period, avoiding the manipulation of birds and discarding interferences from the time of collection in relation to the circadian hormone cycle. As these animals are sensitive to handling by the researcher, this form of collection minimizes the influence of the restraint stress on the final results (DEHNHARD et al., 2003).

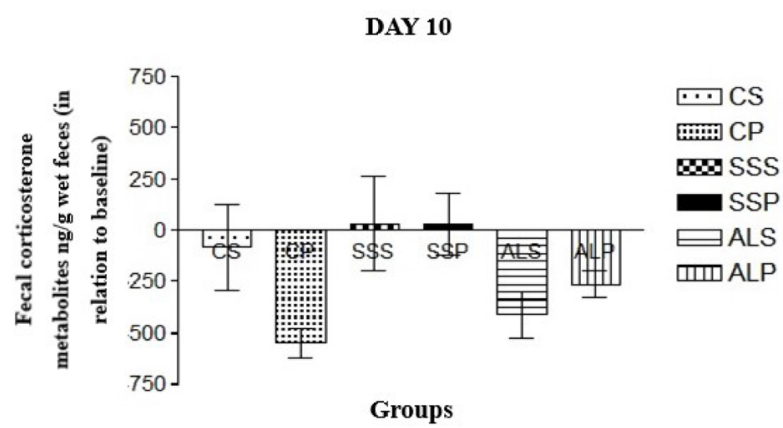

Graph generated after statistical analysis, by the program Prism 3.0, from the data obtained in this experiment.

Figure 5. Evaluation of fecal corticosterone metabolites in quails subjected to experimental wounds and different hemostatic protocols. Data are represented as mean + standard error. (CS = Control group with superficial wound; $\mathrm{CP}=$ Control group with deep wound; SSS = Quick Blood Stopper ${ }^{\circledR}$ group with superficial wound; SSP = Quick Blood Stopper ${ }^{\oplus}$ group with deep wound; ALS $=$ Alveolex $^{\circledast}$ group with superficial wound; ALP = Alveolex ${ }^{\circledR}$ group with deep wound). 


\section{CONCLUSION}

The study showed that propolis-based hemostatic dressing $\left(\right.$ Alveolex ${ }^{\circledR}$ ) brought more promising results: ease of handling during the transoperative period, rapid hemostasis, without delaying healing or impairing bird health. Ferric subsulfatebased hemostatic dressing (Quick Blood Stopper ${ }^{\circledR}$ ) was more difficult to handle and apply, interfering negatively with tissue healing.

\section{REFERENCES}

ARAÚJO, J. L. et al. Are anti-ganglioside antibodies associated with proventricular dilatation disease in birds? Peer] Preprints. 5:e3144, Apr, 2017.

BALSA, I. M.; CULP, W. T. N. Wound care. Veterinary Clinics of North America: Small Animal Practice. v. 45, n. 5, p. 1049-1065, 2015.

BOTELHO, G.G. et al. Physiological performance of quails that underwent dietary and pharmacological manipulation of cholesterol. Animal Physiology and Animal Nutrition. v. 99, p. 424-429, 2015.

BROWN, J. L.; WALKER, S. E.; STEINMAIN, K. Endocrine Manual for the Reproductive Assessment of Domestic and Non-Domestics Species. Conservation and Research Center, Smithsonian's National Zoological Park, Front Royal, Virginia, USA, 2004.

BYUN, J-Y. et al. Comparison of hemostatic efficacy and cytotoxicity of three ferric subsulfate- and chitosan-based styptics in different formulations using a rat tail bleeding model. Korean Journal of Veterinary Research. v. 58, n. 3, p. 119-124, 2018.

CAMPBELL, T. W. Hematology of Psittacines. In: Weiss, D. J.; Wardrop, K. J. Schalm's Veterinary Hematology. 6. ed. lowa: State Avenue, 2010. cap. 123, p. 968-976.

DAVALOS, D.; AKASSOGLOU, K. Fibrinogen as a key regulator of inflammation in disease. Semin Immunopathol. v. 34, p. 43-62, 2012.

DEHNHARD, M. et al. Measurement of plasma corticosterone and fecal glucocorticoid metabolites in the chicken (Gallus domesticus), the great cormorant (Phalacrocorax carbo), and the goshawk (Accipiter gentilis). General and Comparative Endocrinology. v. 131, p. 345-352, 2003.

DURANT, S. E. et al. Wound-healing ability is conserved during periods of chronic stress and costly life history events in a wildcaught bird. General and Comparative Endocrinology. v. 229, p. 119-126, 2016.

FAIR, J.; WHITAKER, S.; PEARSON, B. Sources of variation in haematocrit in birds. Ibis. v. 149, n. 3, p. 535-552, 2007.

GEORGIEVA, T. M. et al. Effects of Escherichia coli infection and Eimeria tenella invasion on blood concentrations of some positive acute phase proteins (haptoglobin (PIT 54), fibrinogen and ceruloplasmin) in chickens. Revue de Médecine Vétérinaire. v. 161, n. 2, p. 84-89, 2010.
HOLLANDER, J. E. et al. Wound registry: development and validation. Annals of Emergency Medicine. v. 25, n. 5, p. 675-684, 1995.

KENNETH, L. S.; BIENZLE, D. Determination and Interpretation of the Avian Leukogram. In: Weiss, D. J.; Wardrop, K. J. Schalm's Veterinary Hematology. 6. ed. lowa: State Avenue, 2010. cap. 50, p. 345-357.

LICHTENBERGER, M. et al. Comparison of fluid types for resuscitation after acute blood loss in mallard ducks (Anas platyrhynchos). Journal of Veterinary Emergency and Critical Care. v. 19, n. 5, p. 467-472, 2009.

LUMEIJ, J. T. Avian Clinical Biochemistry. In: Kaneko, J. J.; Harvey, J. W.; Bruss, M. L. Clinical Biochemistry of Domestic Animals. 6. ed. New York: Academic Press, 2008. cap. 28, p. 839-872.

MICKELSON, M. A.; MANS, C.; COLOPY, S. A. Principles of Wound Management and Wound Healing in Exotic Pets. The veterinary clinics of North America. Exotic animal practice. v. 19, n. 1, p. 33-53, 2016.

PEREIRA, N. T. et al. Effect of alveolex on the bone defects repair stimulated by rhBMP-2: Histomorphometric study. Microscopy Research and Technique. v. 75, n. 1, p.36-41, 2012.

PORTOU, M. J. et al. The innate immune system, toll-like receptors and dermal wound healing: A review. Vascular Pharmacology. $v$. 31, p. 31-36, 2015.

RITZMAN, T. K. Wound healing and management in psittacine birds. The Veterinary Clinics of North America. Exotic Animal Practice. v. 7, n. 1, p. 87-104, 2004.

SCARANO, A. et al. Hemostasis control in endodontic surgery: a comparative study of calcium sulfate versus gauzes and versus ferric sulfate. Journal of Endodontics. v. 38, n. 1, p. 20-23, 2012.

SEHN, E.; et al. Dynamics of reepithelialisation and penetration rate of a bee propolis formulation during cutaneous wounds healing. Analytica Chimica Acta. v. 635, n. 1, p. 115-120, 2009.

SINGER, A. J. et al. Development and validation of a novel scar evalution scale. Plastic and Reconstructive Surgery. v.127, п. 7, p. 1892-1897, 2007. 